\title{
Report
}

\section{Unsustainable Management of Forests in Ghana from 1900-2010}

\section{Ikpe Emmanuel Quacou}

Department of Environmental Science and Engineering, Suzhou University of Science and Technology, Suzhou, China

\section{Email address:}

quacouikpe@gmail.com

\section{To cite this article:}

Ikpe Emmanuel Quacou. Unsustainable Management of Forests in Ghana from 1900-2010. International Journal of Environmental Monitoring and Analysis. Vol. 4, No. 6, 2016, pp. 160-166. doi: 10.11648/j.ijema.20160406.14

Received: June 4, 2016; Accepted: November 24, 2016; Published: January 3, 2017

\begin{abstract}
Forests play important roles in maintaining and balancing the natural ecosystem. The high rates of deforestation in recent years however have become concerned for all governments all over the world. The high rates have resulted in a number of climatic changes such as global warming with its effects on the global environment giving rise to sea levels and the resultant adverse effects. The role of forest cover in hydrological and carbon cycles in the atmosphere is enough evidence of its importance and the need to protect its cover. Between 1900 and 1999, more than 6.5 million hectors of forest was degraded in Ghana according to a report published at the website of mongabay.com. Further, between 1990 and 2010, the country lost an average of 125,400 hectors of forest or $1.68 \%$ per year. In total, between this period alone, Ghana lost $33.7 \%$ of its forest cover which is equivalent to 2,508,000 hectors of forest, (FAO, 2011). This data reveals that the rate of detestation in Ghana is quite high. Deforestation is one of the main environmental challenges in Ghana and efforts are being undertaken to protect the endangered forest cover from absolute depletion and also to establish secondary forests.
\end{abstract}

Keywords: Deforestation, Natural Resource, Sustainable Use of Resources, "Gallamsey"-Illegal Surface Mining

\section{Introduction}

Ghana is located in West Africa along the coast of Gulf of Guinea. It has a total land area of $238,537 \mathrm{~km}^{2}$. It has about 27 million people according (2010) National Population and Housing Census and has a population growth rate of $1.78 \%$ per annum and has an average life expectancy of 61.45 years.

The three main exports of Ghana are Gold, cocoa and timber. These products are mainly found in the country's forest regions as shown in figure 1. The deep and light green regions of the map are the main forest areas which also represent the main cocoa growing areas of the country. Gold, bauxite and diamond are also mostly found in these regions of the country. Thus, it can be said that the exploitation of these resources for either domestic use or for export have also contributed to deforestation in the country. There are other causes such bush fires and unsustainable agricultural systems among others.

One of the numerous resources that the country has is its natural forests which give it unique and diverse forest resources and tropical climatic and environmental conditions. This had given the country unique climatic conditions until the 20th century when the rate of exploitation increased as a result of population increase and the need for development of infrastructure. Other natural resources that the country has include gold, diamond, bauxite manganese among others.

In the recent years however, these natural forests have been under pressure of exploitations for the growing population. This has some direct effect on the high rates of deforestation and their negative effects on the environment are so obvious.

According to www.mongabay.com (2014), available data indicates that between 1900 and 1950, 4.2 million hectares of forests were degraded in Ghana out of a total of 8.4 that the country had at the beginning of the century. This was further degraded to only 1.9 million hectares by 1999 . This is a clear indication that the rate of deforestation in Ghana has become critical and this needs attention in order to save the country's forest resources from total depletion.

The aim of this article is to highlight some identified causes of deforestation. In addition, the article will examine 
effects of the rate of deforestation on the country's environment and climate. Some suggestions will be made as to how this trend of deforestations could be slowed down.
Finally, practical measures that have been taken so far in aforestation programs and their successes will also be highlighted.

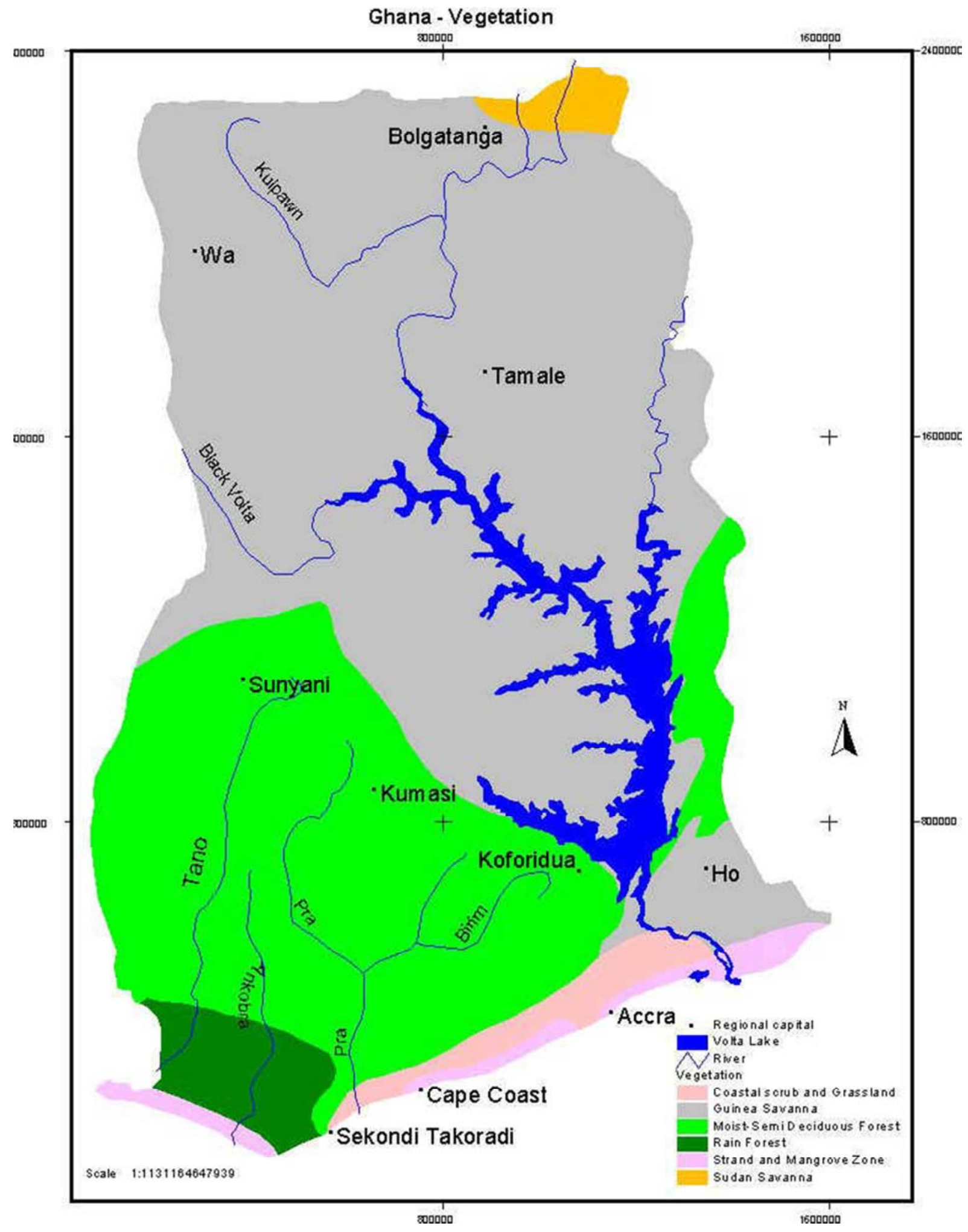

Figure 1. Vegetation map of Ghana.

\section{Deforestation}

A forest ecosystem is natural woodland unit consisting of all plants, animals, and microorganism (biotic) in that area functioning together with all of the non-living physical (a biotic) factors of the environment. This means that definition of forest is not limited to only plants but includes animal 
species as well as a-biotic factor such as soils and other minerals since there is an interdependence and interrelationship among all the factors that make up forest. For example the plants cannot grow without the soils and the minerals salts which they need as their sources of nutrients.

Deforestation is the clearing, destroying or removal of trees and other plant species through deliberate, natural or accidental means for various reasons.

Deforestation in Ghana is caused mainly by anthropogenic factors rather natural factors.

A study, described by its authors as the most comprehensive analysis of tropical forests, has disclosed that Ghana has the highest rate of deforestation, out of 65 nations, apart from Togo and Nigeria. The illegal act of felling trees has become one of the commonest offences in Ghana today, some culprits are caught by the law, the fortunate ones are never caught, while others are sometimes deliberately let go by guardians of the law. The study further reveals that Ghana looses 2.19 percent of forests a year. Every day, the forest zones of the country is tampered with legally or illegally, making one wonder what would become of the nation's forest resources in the next 50 years.

According to the annual report (FAO, 2010), 13 million hectors of forest is lost per year globally and Africa alone contributes 3.4 million hectors of this loss per year. The situation is not different in Ghana where deforestation is also quite high. The country has a total land area of 23.85 million hectares. At the beginning of the 20th century, 8.2 million hectors of this area was covered by forest and the rest by other types of vegetation such as Sudan and guinea savannahs. Forest cover however keeps reducing and by 1950s, it had been reduced by half to about 4.2 million hectares. It was further reduced to about only 1.9 million hectares by 1999 . Recent data from www.mongabay.com indicated that between 1990 and 2000 alone, within a period of ten years, the annual deforestation rates in Ghana were 1.8\%. The FAO 2010 annual report also indicated that the rate of annual deforestation in Ghana is about 135, 935 hectares per year. Figure 2 shows the trend of deforestation in Ghana between 1900 and 1999.

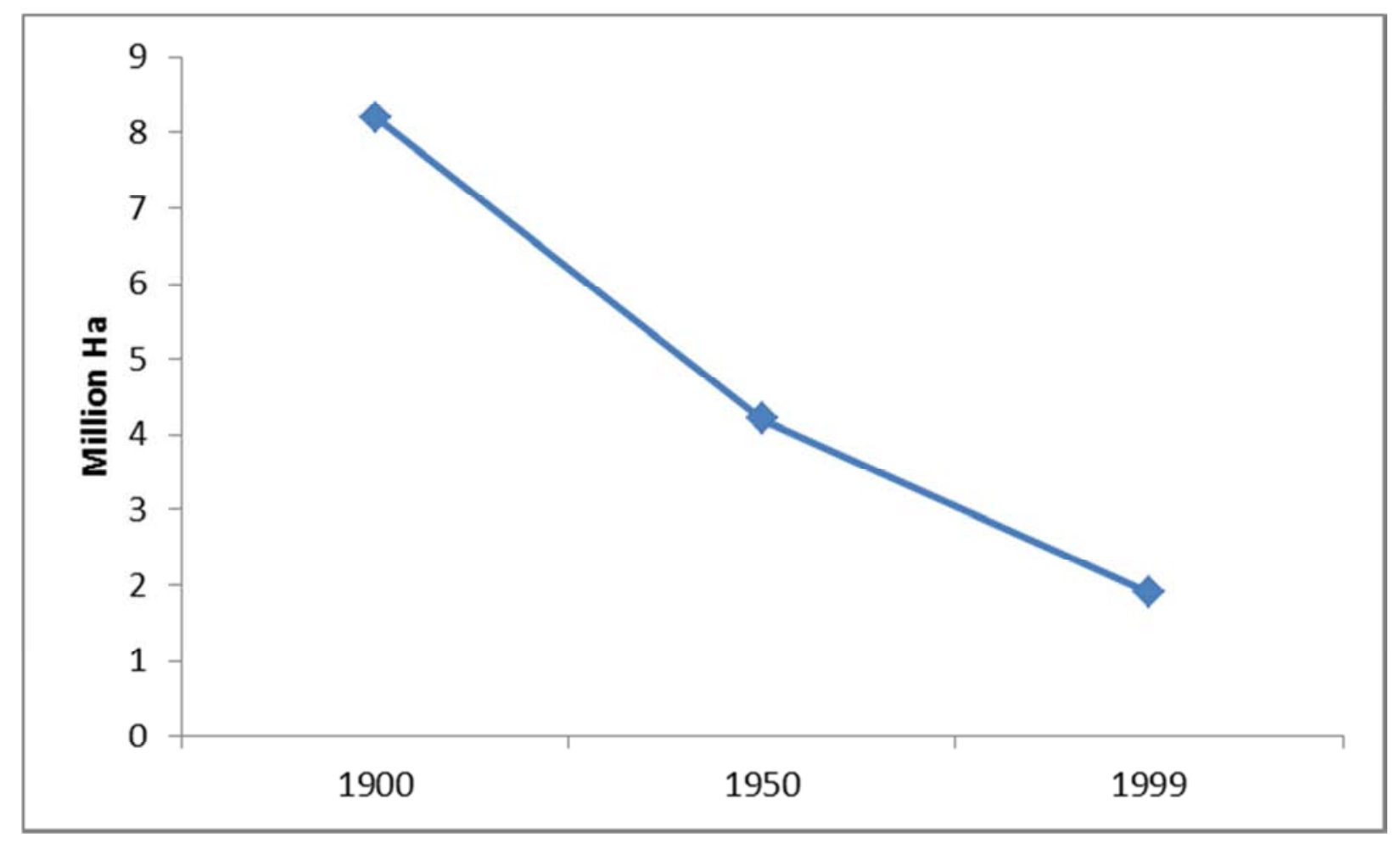

Source: www.mongabay.com

Figure 2. Trend of deforestation form 1900-1999.

\section{Causes of Deforestation in Ghana}

There are several factors that account for the high rate of deforestation in Ghana. These causes are not independent and most of them are interrelated. Majority of the primary causes of deforestation in Ghana are anthropogenic and can be linked to livelihood, survival and development at both the sub national and national level. At the national level for example, timber accounted for the fourth highest foreign exchange earner for the country in 2014. A total of about $249,846 \mathrm{~m}^{3}$ of timber worth $€ 98.5$ million was exported in the first three quarters of 2014 alone. (Ghanaian Times news paper, 23January 2015 edition). This contributes significantly to the rate of deforestation in the country. At the sub national level, agriculture employs about $60 \%$ of the population directly or indirectly. All the activities of the population engaged in the agriculture sector also have direct contribution to deforestation rates in the country. These causes can further be classified into indirect and direct causes. The indirect causes are those factors which actually trigger deforestation. 


\section{Ghana Land Use / Land Cover Change}

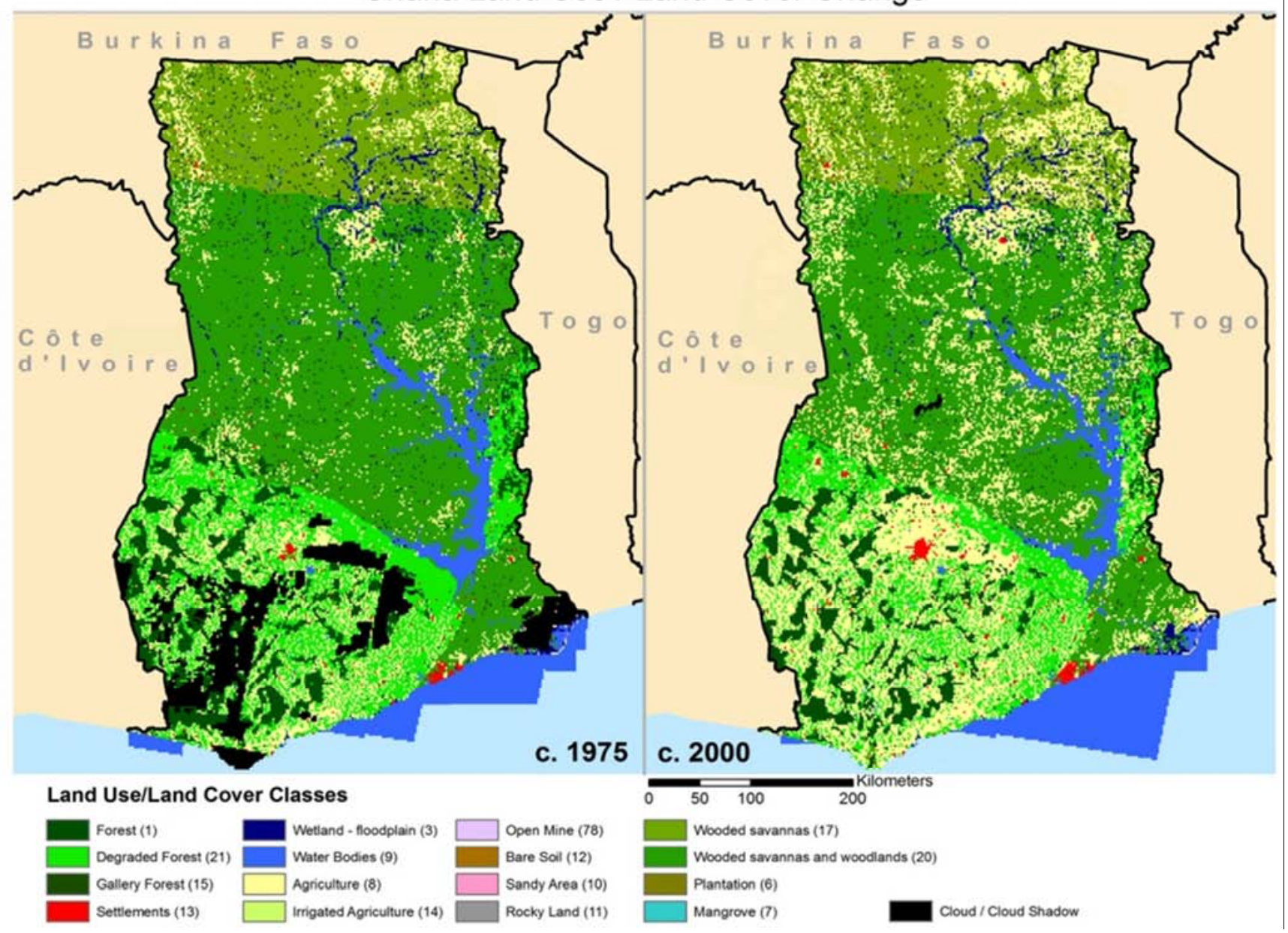

Figure 3. Ghana land use/cover change.

One of the main causes of deforestation in Ghana is agriculture. Ghana was the leading producer of cocoa until 1985 when she was overtaken by Ivory Coast. Most of these cocoa farms are found in regions where there used to be tropical rain forest. These forests have therefore been cleared and cocoa farms have been cultivated instead. Since then, the rate of deforestation started increasing since farmers were encouraged to grow cocoa as it was the cash crop that earned them income as well as foreign exchange for the government. One can therefore draw a link between the introduction of cocoa and its cultivation in Ghana to the rate of deforestation between 1900 and 1950. As the nation's forests were cleared to cultivate cocoa for export for foreign exchange, little did we know that we were also creating another problem of deforestation? In a related development, shifting cultivation is also contributing to the rate of deforestation. Since the soils are losing their fertilities due to continuous crop cultivation, famers are always looking for virgin or fresh forest where they are assured of rich soils for higher yields. Figure 3 shows the land cover change of Ghana's forest between 1975 and 2000 within 25 year. According to United States Geological Survey (USGS 2013), agriculture land occupied $31,552 \mathrm{~km}^{2}$ in 1975 . This figure increased to $61,998 \mathrm{~km}^{2}$ representing an increase of $96.5 \%$. This thus supports the fact that agriculture is one of the primary causes of forest cover loss in the country.

Another major cause of deforestation in the country is logging. Some timber merchants have been given concessions by the government for logging of timber products for domestic and export markets. Timber is currently the fourth foreign exchange earner for the country. From January to September 2014 , timber alone contributed an amount of $€ 98.5$ million as foreign exchange. For a quantity of $249,846 \mathrm{~m}^{3}$ of timber to be taken from the nation's forest for only three quarters year 2014 alone, one can imagine the acreage of forest that was lost in the process. In addition, there are also illegal "chain saw machine operators" who also do their illegal logging activities and are destroying forest resources.

Further, mineral exploitation in the forest zones is another cause of deforestation in Ghana. Mining activities especially mining of gold by both the licensed mining companies and illegal mining groups who are locally called "gallamsey mining" also cause damage to the nation's forest reserves. Most of the gold and other mineral deposits in Ghana are found in Ashanti, Central, Western, Eastern and Brong Ahafo Regions. These regions are equally the home of about $70 \%$ of 
the nation's tropical rain forests. Therefore the mining of gold in these forests is also contributing to degradation of forest cover since the forest will have to be cleared before mining takes place. What is even worrying is the type of mining that is done. Surface mining in these forest regions contributes to deforestation than underground mining. Most of the mining companies within last twenty years prefer to do surface mining where large tracks of forests are cleared and the soils are turned using various heavy duty machines in search of gold. The only reason one can subscribe to this is probably the fact that investment cost of surface mining is relatively lower than the deep mining. Even though the licensed mining companies are supposed to have land restoration and aforestation programs to restore the degraded land including forests back to almost their original state, most of them do not do it after their mining activities. The national institutions which are supposed to supervise the implementation of these regulations are also "sleeping" whiles the nation's forests are being depleted without replacement. The "gallamsey" mining groups are the most dangerous as their activities are illegal and they destroy forest resources without regards any to environmental protection laws and regulations. Some of them can even divert the natural course of rivers and mine gold in the river bed irrespective of the damage to the environment.

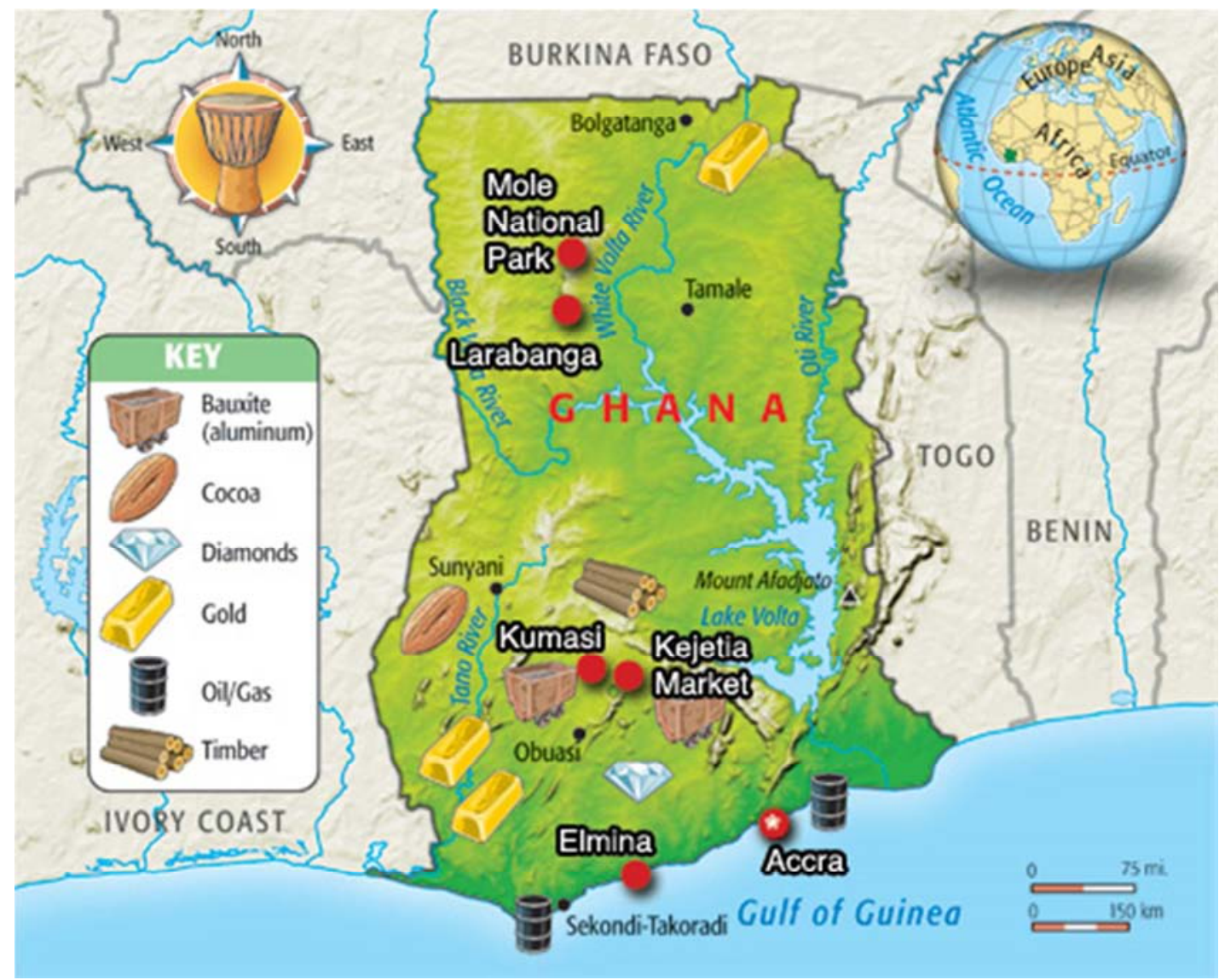

Figure 4. Minerals deposit map of Ghana.

There are other causes such as urbanization, developmental activities such as road construction and bush fires among others.

\section{Negative Effects of Deforestation in Ghana}

Even though this article is focusing on the negative effects of deforestation in Ghana, the effects are not different from what has been known and documented. This section will highlight some negative effects with emphasis on those effects which are specific and particular to Ghana.

One of the known effects of deforestation is global warming with its associated negative impacts on the environment. It is researched and reported that global temperatures are rising at annual rate of $1^{\circ} \mathrm{C}$ per annum. This further causes rise in sea level as result of the melting of the ice in the Polar Regions and damages life and property along coastal countries.

One of such effects in Ghana is the rise in the sea level causing damage to property along the coastal regions, especially along the coast of southern Ghana in the gulf of Guinea. This is evident by the washing away of parts of coastal communities of Keta and Ada along the coast of Gulf of Guinea in the southern Ghana. In 1988, Government of Ghana spent $\$ 83$ million (Coastal Engineering, 1998) to construct Keta Sea Defense wall to prevent the sea from further damage to property of these communities.

Another effect as reported by Peter Don Tindan (2013) in a study conducted in the Ghana is that deforestation leads to soil degradation. The removal of tree covers and continues 
exposure of bare soils to excessive sun light and rainfalls reduces soil fertility. The ultimate effect of this is that the crop yield per unit of land keeps reducing. This in the final analysis threatens the livelihood of the communities who depend on forest for their livelihood.

Another typical effect of deforestation in Ghana is the drying up of headwaters of water bodies which supplies water to major cities in the country. Between 2010-2012, there were continues drought along the River Owabi which is a major source of water supply to Kumasi, the second largest city in Ghana. The major causes of this are deforestation activities that are being undertaken along the head waters of the river. This resulted in the acute potable water shortage in the city during the period.

\section{Measures to Mitigate Effects of Deforestation in Ghana}

What can done is to encourage the intensive system of farming in which modern methods such as the application of fertilizers in the environmentally acceptable methods so the yield per unit area of land is increased whilst the excessive use of fertilizers are also avoided. The recent introduction of national fertilizers subsidy to famers in the country was a step in the right direction. What needed to be done was for the user application of these fertilizers to have been incorporated into the program in order to save the soils and the water bodies. In this way, famers can change from shifting cultivation to intensive form of food production in which one piece of land can be cultivated intensively and the yield could still be high. These will safe our forests from further degradation to some extent.

Another measure that can be taken is to strengthen the National Forestry Commission of Ghana to perform its mandate for which it was established. This Commission was established to protect the nation's forest resources and also to design programs for national aforestation efforts. However, little had been seen of this Commission in the past hence the time to make them resourceful to be able to deliver on their mandate is now. If the Forestry Commission could collaborate with communities to form what is known as Community Forest Protection Guards (CFPG), it will help reduce the activities of the illegal logging in the forest reserved areas. This has proven to work well in communities where this has been piloted. The community members live closer to the forest reserves than the forestry officials who mostly live and work in the big cities. With such deep community involvement, the community members can "police" the forests against illegal activities such as illegal logging. In addition to this, community members can be supported to form what I prescribe as the Community Fire Volunteers (CFV) to protect the forest against bush fires especially during the dry seasons during which most bush fires occur in the country.

In addition, the national institutions must implement the forestry protection laws that exist and the national parliament must also pass appropriate laws to protect the few forest reserves that are left from further degradation. Offenders of such laws must be dealt with without fear or favor. In addition, all gold mining companies already given permit for surface mining should be supervised by the relevant state institutions to ensure that their environmental management plans are implemented to the letter. Further, as surface mining has been identified as one of the major causes of deforestation in recent times, it is suggested that no company should be permitted to do surface mining in our forest regions. It is however difficult to implement this as there is no specific law in Ghana forbidding surface mining in the country. Parliament may therefore consider passing an appropriate law restricting granting of license to companies for surface mining. In the same way all the timber logging companies must be made to implement their aforestation programs as part of their permits on sustainable basis such that the nation can begin to regenerate its degraded forest reserves.

Last but not the least, there must be constant public education on the dangers of such negative practices that lead to deforestation and their implication on the environment. The Environmental Protection Agency together with other government institutions such as the Forestry Commission of Ghana must also be up and doing and carry out their mandates so that the few acreage of nation's forests reserves that are left can be protected to save our environment for posterity.

\section{Current Aforestation Initiative in Ghana}

Despite this glooming picture, there have been some attempts by the government to undertake various aforestation programs in order to regenerate the nations degraded forests. One of such programs is the Ghana Forest Plantation Strategy 2012-2040. This is a follow up action after the XII World Forestry Congress (WFC) held in Buenos Aires in 2009 and the United Nation Conference on Sustainable Development (UNCSD) in Rio de Janeiro in 2012. This is part of the strategy to derive more opportunities from the forest resources by way of goods and services and that these programs will also contribute to climate mitigations measures as well as degraded land restorations and other environmental benefits of forests. A program known as Ghana National Forestry Plantation Development Program (GNFPDP) has been developed out of the strategy to do aforestation program in the country. The ultimate goal of this program is to first of all to halt the alarming deforestation rate in the country and secondly to initiate vigorous and pursue a national aforestation program to restore the lost forest cover. It is refreshing to note that this program has made adequate provision for private sector participation to ensure its successful implementation with the expected outputs and outcomes.

Some successes have been achieved out of this program and these include the formulation and revision of National Legal and Policy Framework to protect the environment in general and forest in particular. The following are some of the Legal and policy framework that have been formulated and revised 
in this regard to give legal backing to these laudable initiatives. Some of the legal instruments have also been revised and amended to meet the current situation.

1. Forest and Wildlife Policy, 1994

2. Ghana Forest and Wildlife Policy, 2012

3. National Climate Change Policy, 2012 (CDM, REDD+)

4. Forest Plantation Development Fund (FPDF) Act, 2000, Act 583

5. Forest Plantation Development Fund (Amendment) Act, 2002, Act 623 (items (iii),

6. (iv) and (v) support public and private investment in forest plantation development

7. The Timber Resources Management (Amendment) Act, 2002, Act 617 (excludes private forest plantations from being allocated by government under a Timber Utilization Contract (TUC), in addition to the provision of fiscal and other incentives and benefits to forest plantation investors among others).

In addition to the above legal reforms to support the aforestation program, the actual implementation of the aforestation program has started and some progress has been made. A lot of work still remains to be done in this area to boost the aforestation programs. Figure 5 gives the trend of the number of hectors of aforestation program implemented from the GFPS form 2002 to 2012. There was an increase in the acreage of both the private and public sectors of acreage of aforestation between 2002 and 2004 at the onset of the program. There was however a decline from 2004 for a four year period to 2008 after which there was a marginal increase again between 2008 and 2010. The general trend in figure 5 does show any continuous increase in the program as one would have expected on yearly basis. The graph also indicates that the public sector's contribution in terms acreage has been more than the private sector. The private sector's participation in the program is however an indication that given the necessary support and incentives, their contribution could increase as the program is being implemented. This will eventually lead to the success of the aforestation program in order to increase the lost forest cover and to safe the biodiversity in the forest from absolute depletion and extinction.

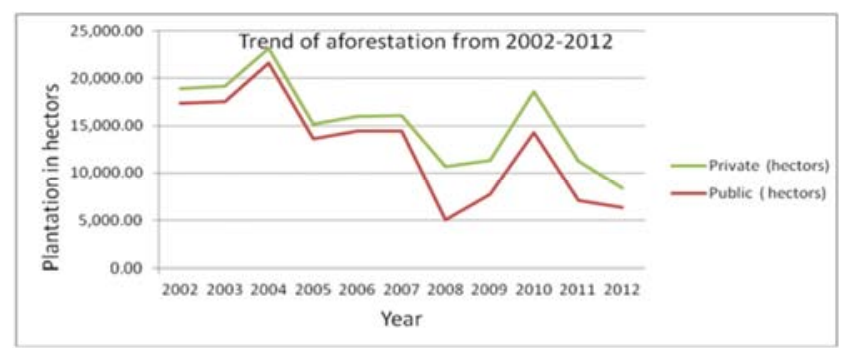

Figure 5. trend of pubkicGraph of comparative contribution of public and private sectors to NFPDP.

In as much as this achievement cannot be compared to the acreage of forest that has been degraded from 1900 to the present day, it will go a long way to restore the lost forest cover if the momentum with which this program began can be sustained. It is therefore hoped that this will go a long way to restore the nation's forest cover lost and reduce its negative effects on the environment.

\section{Recommendation}

The rate of deforestation in Ghana is a real treat to the natural environment and there is evidence available to support this. Ghana must therefore take the necessary steps to prevent further degradations of the country's forest by enforcing the existing forest protection laws such as the Forest Plantation Development Fund (Amendment) Act and The Timber Resources Management (Amendment) Act. Further, the private sector should be given incentives to participate in the aforestation program as figure 5 suggests that given the needed support, it can play significant role to complement the public sector in the various aforestation programs. In addition, there should be intensive education on the implications of the various farming systems on deforestation. Ultimately, Ghana will have to intensify its efforts in aforestation programs taking into consideration the rate at which the forests have been degraded over the years. Deforestation has actually been described in some environmental literature as a "timing bomb" and its explosion can be prevented by instituting various aforestation programs alongside other environmental pollution control strategies.

\section{References}

[1] FAO (2006 \& 2010) annual report.

[2] Reginald Guuroh, (2010), Forest degradation and deforestation in Ghana.

[3] Ghana Forest Plantation Strategy 2012-2040 (2013).

[4] Peter Dok Tindan (2013), The causes of and impact from deforestation on local level sustainable forest management in Ghana. A survey of Dwease and Praaso communities in the Ashanti Region.

[5] Forest and Wildlife Policy, 1994.

[6] Ghana Forest and Wildlife Policy, 2012.

[7] National Climate Change Policy, 2012 (CDM, REDD+).

[8] Forest Plantation Development Fund (FPDF) Act, 2000, Act 583.

[9] Forest Plantation Development Fund (Amendment) Act, 2002, Act 623 (items (iii), (iv) and (v) support public and private investment in forest plantation development.

[10] The Timber Resources Management (Amendment) Act, 2002, Act 617. 